\title{
Evaluation of Onion Cultivars for Resistance to Enterobacter cloacae in Storage
}

\author{
B. K. Schroeder, Washington State University, Pullman 99164; T. D. Waters, Washington State University, Franklin \\ Co. Extension, Pasco 99301; and L. J. du Toit, Washington State University, Mount Vernon NWREC, Mount Vernon \\ 98273
}

\begin{abstract}
Schroeder, B. K., Waters, T. D., and du Toit, L. J. 2010. Evaluation of onion cultivars for resistance to Enterobacter cloacae in storage. Plant Dis. 94:236-243.

Sixty-nine storage onion (Allium cepa) cultivars (seven white, five red, and 57 yellow cultivars) were evaluated in the Washington State University Onion Cultivar Trials in the semiarid Columbia Basin of central Washington in 2007-08 and/or 2008-09. Each cultivar was inoculated with Enterobacter cloacae, cured, stored under commercial storage conditions, and evaluated for bacterial storage rot symptoms approximately 4.5 months after storage. Noninoculated bulbs of each cultivar served as a control treatment in each experiment. In addition, bulbs injected with water served as a second control treatment in the 2008-09 experiment. Inoculation of onion bulbs with $E$. cloacae resulted in significantly higher incidence and severity of Enterobacter bulb decay compared to noninoculated bulbs and bulbs injected with sterile water. For bulbs inoculated with E. cloacae, mean severity of bacterial storage rot per cultivar ranged from 5 to $19 \%$ of the cross-section evaluated for each onion bulb in 2007-08 and from 9 to $29 \%$ in 2008-09. For noninoculated bulbs, mean severity ranged from 0 to $1 \%$ in $2007-08$ and 0 to $3 \%$ in 2008-09. For bulbs injected with water in the 2008-09 experiment, severity of bulb rot ranged from 0 to $10 \%$ per cultivar, with four cultivars (OLYX05-26, RE-E, Redwing, and Talon) displaying bulb rot ratings significantly greater than $0 \%$. For the 33 cultivars included in both experiments, a significant correlation in bulb rot severity ratings was detected for the 2007-08 versus 2008-09 experiments ( $r=0.43$ at $P=0.013$ ). Redwing, Red Bull, T-433, Centerstone, and Salsa had low severity ratings in both experiments; whereas Montero, OLYS05N5, Caveat, and Granero had severe bulb rot ratings in both experiments. The results demonstrate that it should be possible to select for increased resistance to Enterobacter bulb decay in storage onion cultivars.
\end{abstract}

Enterobacter bulb decay was recently reported as a storage rot of onion (Allium cepa) bulbs in Washington State (29). The disease was also reported from onion production regions of California and Colorado (2,35), but is not considered a widely prevalent disease of onion in the United States (11). Enterobacter bulb decay is caused by the bacterium Enterobacter cloacae (2), but very little is known about this pathogen. The pathogen presumably colonizes onion plants in the field and may be present in or on the bulbs as latent infections at harvest. Infection of mature bulbs by $E$. cloacae was reported for bulbs removed directly from the field prior to storage (2). However, to our knowledge preharvest symptoms of onion plant or bulb infection by E. cloacae have not been reported. Bulb rot symptoms that develop in storage are characterized by a light brown discoloration of the internal fleshy

Corresponding author: Brenda K. Schroeder E-mail: bschroeder@wsu.edu

* The $\boldsymbol{e}$-Xtra logo stands for "electronic extra" and indicates that Figure 1 appears in color in the online edition.

Accepted for publication 6 October 2009.

doi:10.1094/PDIS-94-2-0236

(C) 2010 The American Phytopathological Society scales (Fig. 1A and B). The rot typically begins in the center scales toward the neck of the bulb and progresses in the direction of the basal plate $(2,29,35)$. There is no odor associated with the rot, and the discolored scales tend to maintain integrity compared to the watery breakdown of fleshy bulb scales caused by soft rotting bacterial pathogens such as Pectobacterium carotovorum subsp. carotovorum and Dickeya spp. (11,34). This makes it almost impossible to detect Enterobacter bulb decay in storage without sampling and dissecting the bulbs.

E. cloacae is a member of the Enterobacteriaceae and is ubiquitous in nature (24). The bacterium is commonly isolated from humans, plants, insects, water, soil, and sewage $(8,14,16,24)$. Interestingly, the bacterium is an opportunistic human pathogen that can cause nosocomial infections (28), as well as a pathogen of numerous plant species, including elm (Ulmus sp.) (4,17), corn (Zea mays L.) (25), apple (Malus domestica) (26), papaya (Carica papaya) (19), coconut (Cocos nucifera) (12), macadamia nut (Macadamia integrifolia) (20), ginger (Zingiber officinale) (18), orchids (36), mung bean (Vigna radiata) (38), and onion bulbs $(2,9,29,35)$. $E$. cloacae can infect actively growing orchids, elm trees, and corn $(4,17,25,36)$, and was demonstrated to cause postharvest infections of papaya, ginger, macadamia nut, and onion (2,18-20). These high-value crops appear to be infected by E. cloacae during the growing season, with the pathogen then surviving in the stored plant tissues. When the storage plant tissues reach a physiological stage that is more susceptible to the bacterium and/or when environmental conditions become favorable for development of E. cloacae (e.g., low oxygen, high moisture, or high temperatures), disease symptoms appear (2,18-20). In most cases, the source of inoculum remains unknown, although soil may be a reservoir of the pathogen (24). In addition, there is empirical evidence that manure use in onion crops may increase the incidence or severity of Enterobacter bulb decay (11). In papaya crops, E. cloacae has been isolated from fruit flies (19). The mechanism of entry of the pathogen into plant hosts is unknown, although isolation of $E$. cloacae from papaya flowers suggests flowers may provide an infection court (19). Currently, the limited knowledge of how E. cloacae interacts with host plants complicates efforts to understand the epidemiology and host-pathogen interactions of this bacterial pathogen and, ultimately, the development of effective disease management programs.

Increasing our understanding of variability in resistance to E. cloacae in storage onion cultivars could enable onion breeders to select for greater resistance in onion germplasm to reduce losses to this disease, and assist growers in selecting less susceptible cultivars for planting in areas with a history of Enterobacter bulb decay. The objective of this study was to assess the response of onion storage cultivars to inoculation with $E$. cloacae. Onion cultivars evaluated during the 2007-08 and 2008-09 Washington State University Onion Cultivar Trials in the semiarid Columbia Basin of Washington State were screened for resistance to E. cloacae. The cultivars evaluated in this annual trial represent the diversity of storage cultivars produced in this long daylength region of onion production (23), as well as experimental cultivars being developed for commercial production. Preliminary results have been presented $(32,33)$.

\section{MATERIALS AND METHODS}

Onion cultivar trials. This study was completed in coordination with the 200708 and 2008-09 Washington State University (WSU) Onion Cultivar Trials and Storage Demonstrations (http://benton- 
franklin.wsu.edu/agriculture/OnionProduc tion.html). The 2007-08 trial was located between Paterson and Benton City in the semiarid Columbia Basin of Washington State. Seeds of 55 storage onion cultivars (commercially available hybrids and experimental cultivars) were planted on 22 March 2007 into 110-cm-wide beds with two double rows per bed, using 40-cm spacing between double rows and $7.5-\mathrm{cm}$ spacing within rows. Each cultivar was planted into three replicate plots arranged in a randomized complete block design. Only the first replicate plot of each cultivar was used for the Enterobacter storage decay evaluation in 2007-08. Each plot (experimental unit) was one bed wide and $7.62 \mathrm{~m}$ long. The onion cultivars were planted into a Ritzville silt loam soil with $1.3 \%$ organic matter, $\mathrm{pH} 5.9$, and a slope of 0 to $5 \%$. The cultivars were grown under center pivot irrigation by the grower-cooperator (Hartley Farms) using standard production practices for the area (23). The plants were undercut on 12 September, and bulbs in a 2-m section near the middle of each plot were topped, sized, and harvested by hand on 25 September 2007.

For the 2008-09 WSU Onion Cultivar Trial, seeds of 47 storage onion cultivars (commercially available hybrids and experimental cultivars) were planted in a commercial onion field (Carr Farms) near Pasco in the Columbia Basin on 28 March 2008 into 86-cm-wide beds, with two double rows per bed using $25-\mathrm{cm}$ spacing between rows and $7.5-\mathrm{cm}$ spacing within rows. Each cultivar was planted into three replicate plots using a randomized complete block design. Bulbs from all three replicate plots per cultivar were used in the Enterobacter storage decay evaluation in this trial. Each plot was one bed wide and $9.14 \mathrm{~m}$ long. The onion cultivars were planted into a Kahlotus very fine sandy loam soil with $0.85 \%$ organic matter, $\mathrm{pH}$ 6.4 , and a slope of 0 to $2 \%$. The cultivars were grown under center pivot irrigation by the grower-cooperator, using standard production practices for the Columbia
Basin. The plants were undercut on 9 September, and bulbs in the plots topped and harvested on 15 September 2008 as described for the 2007-08 trial.

Inoculation, storage, and rating of onion bulbs. For the 2007-08 experiment, mature bulbs of four white cultivars, five red cultivars, and 46 yellow cultivars (Table 1) were inoculated with E. cloacae 1 day after harvest. Two days before inoculation, E. cloacae strain ECWSU1 (strain 310 obtained from H. Schwartz, Colorado State University) was grown overnight on a shaker in $5 \mathrm{ml}$ of nutrient broth $(8 \mathrm{~g}$ of nutrient broth, $2 \mathrm{~g}$ of yeast extract, $2 \mathrm{~g}$ of anhydrous $\mathrm{K}_{2} \mathrm{HPO}_{4}, 0.5 \mathrm{~g}$ of $\mathrm{KH}_{2} \mathrm{PO}_{4}, 25$ $\mathrm{ml}$ of $20 \%$ glucose, and $1 \mathrm{ml}$ of $1 \mathrm{M}$ $\mathrm{MgSO}_{4}$ per liter of distilled water) (37) at $28^{\circ} \mathrm{C}$. One day prior to inoculation, a $0.5-$ $\mathrm{ml}$ aliquot of the culture was added to 250 $\mathrm{ml}$ of nutrient broth and incubated overnight on a shaker at $28^{\circ} \mathrm{C}$. Cells of E. cloacae were harvested by centrifugation $(48,800 \times g$ for $10 \mathrm{~min})$ and resuspended to an optical density $\left(\mathrm{OD}_{600}\right)$ of 0.3 (approximately $10^{8} \mathrm{CFU} / \mathrm{ml}$ ) in sterile distilled water. Inoculum was dispensed into sterile test tubes (one tube per cultivar). A $0.5-\mathrm{ml}$ aliquot of inoculum was injected into the upper shoulder of each onion bulb using a syringe and 22 gauge needle (Fig. 1C). The needle was sterilized between bulbs using a cotton swab saturated with 95\% alcohol. A separate test tube and syringe were used for each cultivar. Ten bulbs were selected randomly from within the first replicate plot of each cultivar for inoculation. In addition, 10 noninoculated bulbs per cultivar served as the control treatment. The bulbs were placed in mesh bags in wooden crates in a commercial onion storage facility at Hartley Farms, where they were cured with forced air $\left(32.2^{\circ} \mathrm{C}\right)$ for approximately $24 \mathrm{~h}$. The temperature was then slowly reduced to $1.1^{\circ} \mathrm{C}$ over 7 days, and the bulbs were held at $1.1^{\circ} \mathrm{C}$ and $70 \%$ relative humidity for longterm storage. The bulbs were removed from the bags on 11 February 2008. Each bulb was cut through the center from the neck to the basal plate using a knife, and rated visually for severity of bacterial storage rot symptoms using a scale of 0 to 100 , where $0=$ no symptoms and 1 to $100=$ percentage of the cut surface area with discoloration or rotting characteristic of Enterobacter bulb decay (11).

For the 2008-09 experiment, mature bulbs of four white cultivars, four red cultivars, and 39 yellow cultivars (Table 1) were inoculated with E. cloacae. In contrast with the 2007-08 storage rot evaluations, bulbs from all three replicate plots of each cultivar were inoculated in the 2008 09 experiment to increase the statistical power of the analysis. Bulbs from each replicate plot of each cultivar were inoculated within $24 \mathrm{~h}$ of harvest. E. cloacae strain ECWSU1 was prepared and inoculations completed as described above. A separate tube of inoculum and a separate syringe were used for each cultivar. In addition, the site of inoculation on each bulb was surface-sterilized prior to injection using a cotton swab saturated with 95\% alcohol. The injection site was circled with a permanent black marker to identify the site for bulb rot evaluation after 4 months in storage. An additional modification to the protocol used in 2007-08 was that two control treatments were included in the 2008-09 experiment; in addition to the noninoculated control treatment, which consisted of 10 bulbs per cultivar per replication in 2008-09, a water control treatment was added for which 10 bulbs per cultivar per replication were injected with $0.5 \mathrm{ml}$ of sterile distilled water as described for the E. cloacae inoculations. The bulbs were placed in mesh bags in a wooden crate in a commercial storage facility at Carr Farms, and cured with forced air $\left(32.2^{\circ} \mathrm{C}\right)$ for approximately 10 days. The storage conditions were then reduced to $2.2^{\circ} \mathrm{C}$ over 30 days, and held at $2.2^{\circ} \mathrm{C}$ and $70 \%$ relative humidity for longterm storage. On 10 February 2009, the bulbs were removed from the bags, cut from the neck to the basal plate through the center of the injection site, and rated for severity of bacterial storage rot symptoms as described above.
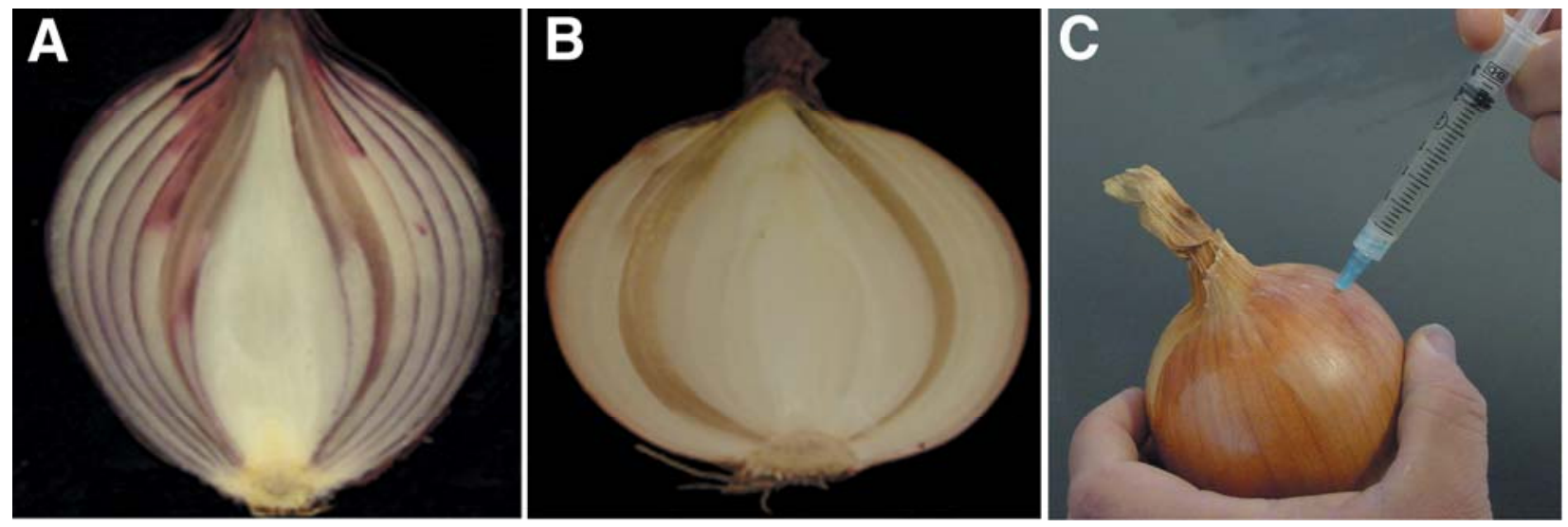

Fig. 1. Symptoms of Enterobacter bulb decay in inoculated bulbs of cultivars A, Redwing and $\mathbf{B}$, Vaquero after 4.5 months of storage in a commercial onion storage facility. C, A $0.5-\mathrm{ml}$ suspension of Enterobacter cloacae was injected into the shoulder of onion bulbs at harvest. 
Bacterial isolations and identification. Five noninoculated onion bulbs with bacterial storage rot symptoms, and one symptomatic bulb selected randomly from each cultivar inoculated with E. cloacae in the 2007-08 experiment, were used to isolate and identify bacteria associated with symptomatic bulbs. In the 2008-09 experiment, four noninoculated onion bulbs with symptoms of bacterial rot and five symptomatic bulbs injected with water were selected randomly for isolations. A 3$\mathrm{cm}$ section of fleshy scale from each bulb was removed from the margin of the symptomatic tissue and placed in $0.6 \% \mathrm{NaOCl}$ for $1 \mathrm{~min}$, rinsed in sterile water for $3 \mathrm{~min}$, and then dried on sterile paper towel in a laminar flow hood for 3 min. A section of the surface-sterilized bulb tissue was placed on nutrient broth yeast extract (NBY) agar plates (37) amended with 50 $\mu \mathrm{g}$ of cycloheximide/ml and streaked across the plate. The plates were incubated at $28^{\circ} \mathrm{C}$ for 24 to $48 \mathrm{~h}$, and representatives of each type of colony morphology were purified by streaking onto NBY twice to obtain single colonies. The bacterial isolates were evaluated for ability to grow anaerobically, degrade pectin, oxidase reaction, and arginine dihydrolase and indole activity $(7,24)$. Facultative anaerobes with arginine activity and no indole activity were designated as putative Enterobacter species and evaluated further using a polymerase chain reaction (PCR) with primers designed from the $16 \mathrm{~S}-18 \mathrm{~S}$ intergenic region that provide a specific DNA profile for species of Enterobacter (8), as described below. To determine whether bacterial pathogens other than $E$. cloacae were present as a result of natural infection in the field, aerobic isolates with oxidase activity were designated as putative Burkholderia species and evaluated using a PCR assay with primers that produce an amplicon of specific size for the onion bulb rot pathogens $B$. cepacia and $B$. gladioli $(1,7,24)$, as described below.
A cell lysis PCR assay (30) was used to screen putative Enterobacter isolates (8). Cells of each isolate were transferred to a 0.2-ml PCR tube using a sterile toothpick, and $24 \mu \mathrm{l}$ of the following reaction mixture was added: 1.25 Units GoTaq Polymerase (Promega, Madison, WI) with $0.3 \mathrm{mM}$ dNTPs, $1 \times$ Colorless GoTaq Buffer, 5.3\% glycerol, 5\% DMSO, 1× polymerase buffer, and $2 \mu \mathrm{M}$ primers T5A (5'-AGT CCGGTGCTCTAACCAACTGAG-3') and T3B (5'-AGGTCGCGGGTTCGAATCC$\left.3^{\prime}\right)$ (8). Parameters for the PCR reaction were $94^{\circ} \mathrm{C}$ for $3 \mathrm{~min}$ to lyse the bacterial cells; followed by $94^{\circ} \mathrm{C}$ for $30 \mathrm{~s}, 50^{\circ} \mathrm{C}$ for $30 \mathrm{~s}$, and $72^{\circ} \mathrm{C}$ for $1 \mathrm{~min}$ for 30 cycles; followed by $72^{\circ} \mathrm{C}$ for $10 \mathrm{~min}$. A $4-\mu \mathrm{l}$ aliquot of $6 \times$ loading buffer with $0.5 \mathrm{mg} / \mathrm{ml}$ RNase A was added to each reaction and incubated at room temperature for 5 to 10 min before electrophoresis in $0.5 \times$ Tris boric acid ethylenediaminetetraacetic acid (0.045 M Tris-borate, 0.001 M Ethylenediaminetetraacetic acid) and visualiza-

Table 1. Response of onion cultivars to inoculation with Enterobacter cloacae in the 2007-08 and 2008-09 Washington State University Onion Cultivar and Storage Demonstration Trials ${ }^{\mathrm{a}}$

\begin{tabular}{|c|c|c|c|c|c|c|c|}
\hline \multirow[b]{3}{*}{ Onion cultivar } & \multirow[b]{3}{*}{ Seed company } & \multirow[b]{3}{*}{ Bulb color } & \multicolumn{5}{|c|}{ Mean severity (incidence) of bacterial storage rot ${ }^{\mathbf{b}}$} \\
\hline & & & \multicolumn{2}{|c|}{ 2007-08 Experiment ${ }^{\mathrm{c}}$} & \multicolumn{3}{|c|}{ 2008-09 Experiment ${ }^{\mathrm{c}}$} \\
\hline & & & $\begin{array}{c}\text { Inoculated } \\
\text { with } E \text {. cloacae }\end{array}$ & Noninoculated & $\begin{array}{c}\text { Inoculated } \\
\text { with } E \text {. cloacae }\end{array}$ & Noninoculated & $\begin{array}{c}\text { Injected } \\
\text { with water }\end{array}$ \\
\hline Montero & Nunhems USA & Yellow & $15.5^{\mathrm{d}}(0.0)$ & $0.0(0.0)$ & $29.0(6.6)$ & $0.0(0.0)$ & $0.0(0.0)$ \\
\hline XON550 & Sakata Seed America & Yellow & - - & -- & $28.0(96.7)$ & $0.0(0.0)$ & $1.3(6.7)$ \\
\hline OLYSO5-N5 & Crookham Co. & Yellow & $17.0(90.0)$ & $0.0(0.0)$ & $26.7(100.0)$ & $0.0(0.0)$ & $3.3(3.3)$ \\
\hline Joaquin & Nunhems USA & Yellow & $6.7(89.0)$ & $0.0(0.0)$ & $26.7(100.0)$ & $0.0(0.0)$ & $0.0(0.0)$ \\
\hline OLYSO3-207 & Crookham Co. & Yellow & $9.5(80.0)$ & $0.1(10.0)$ & $25.7(96.7)$ & $3.3(3.3)$ & $2.3(3.3)$ \\
\hline Affirmed & Seminis Vegetable Seeds & Yellow & $7.5(100.0)$ & $0.0(0.0)$ & $23.7(93.3)$ & $0.0(0.0)$ & $0.3(3.3)$ \\
\hline Vaquero & Nunhems USA & Yellow & $9.0(100.0)$ & $0.0(0.0)$ & $23.0(96.7)$ & $0.0(0.0)$ & $0.0(0.0)$ \\
\hline Ringleader & Nickerson-Zwaan & Yellow & - - & -- & $22.7(93.3)$ & $0.0(0.0)$ & $0.3(3.3)$ \\
\hline XON670W & Sakata Seed America & White & - - & - - & $21.5(90.0)$ & $0.0(0.0)$ & $3.3(3.3)$ \\
\hline Evolution & D. Palmer Seeds & Yellow & $6.5(100.0)$ & $0.0(0.0)$ & $21.0(96.7)$ & $0.0(0.0)$ & $1.3(3.3)$ \\
\hline Caveat & Seminis Vegetable Seeds & Yellow & $10.0(90.0)$ & $0.0(0.0)$ & $20.7(100.0)$ & $0.0(0.0)$ & $1.3(13.3)$ \\
\hline Granero & Nunhems USA & Yellow & $12.0(100.0)$ & $0.0(0.0)$ & $20.3(93.3)$ & $0.0(0.0)$ & $0.0(0.0)$ \\
\hline Pandero & Nunhems USA & Yellow & $9.0(100.0)$ & $0.0(0.0)$ & $20.3(96.7)$ & $0.0(0.0)$ & $1.0(6.7)$ \\
\hline Sedona & Bejo Seeds & Yellow & $8.9(100.0)$ & $0.0(0.0)$ & $20.0(100.0)$ & $0.0(0.0)$ & $0.0(0.0)$ \\
\hline Ruby Ring & American Takii & Red & $8.5(100.0)$ & $0.0(0.0)$ & $20.0(90.0)$ & $0.0(0.0)$ & $1.0(6.7)$ \\
\hline Mesquite & D. Palmer Seeds & Yellow & $7.5(100.0)$ & $0.0(0.0)$ & $19.3(100.0)$ & $0.0(0.0)$ & $0.0(0.0)$ \\
\hline Marquette & Seminis Vegetable Seeds & Yellow & - - & - - & $19.3(93.3)$ & $0.0(0.0)$ & $0.0(0.0)$ \\
\hline Monachos & Seminis Vegetable Seeds & Yellow & $9.0(100.0)$ & $0.0(0.0)$ & $19.0(93.3)$ & $0.0(0.0)$ & $0.0(0.0)$ \\
\hline Arcero & Nunhems USA & Yellow & $10.0(100.0)$ & $0.0(0.0)$ & $19.0(100.0)$ & $0.0(0.0)$ & $0.0(0.0)$ \\
\hline OLYX05-26 & Crookham Co. & Yellow & - - & - & $19.0(96.7)$ & $2.0(3.3)$ & $9.7(20.0)$ \\
\hline Jericho & Seminis Vegetable Seeds & Yellow & - - & - - & $19.0(100.0)$ & $0.0(0.0)$ & $0.0(0.0)$ \\
\hline Cyprus & Seminis Vegetable Seeds & Yellow & - - & - - & $18.7(96.7)$ & $0.0(0.0)$ & $2.7(3.3)$ \\
\hline Delgado & Bejo Seeds & Yellow & $9.0(100.0)$ & $0.0(0.0)$ & $18.7(100.0)$ & $0.0(0.0)$ & $0.0(0.0)$ \\
\hline Milestone & American Takii & Yellow & $9.0(90.0)$ & $0.0(0.0)$ & $18.7(96.7)$ & $3.0(3.3)$ & $2.0(10.0)$ \\
\hline Calibra & Bejo Seeds & Yellow & $9.5(100.0)$ & $0.0(0.0)$ & $18.7(100.0)$ & $0.0(0.0)$ & $0.0(0.0)$ \\
\hline Abilene & Seminis Vegetable Seeds & Yellow & - - & - & $18.3(100.0)$ & $2.7(3.3)$ & $0.7(6.7)$ \\
\hline Pulsar & Nunhems USA & Yellow & - - & -- & $18.3(93.3)$ & $0.0(0.0)$ & $1.3(10.0)$ \\
\hline Tequila & D. Palmer Seeds & Yellow & $18.5(90.0)$ & $0.0(0.0)$ & $18.3(100.0)$ & $0.0(0.0)$ & $3.3(3.3)$ \\
\hline
\end{tabular}

${ }^{a}$ Each cultivar trial was completed in the semiarid Columbia Basin of central Washington in a commercial onion crop using a randomized complete block design with three replicate plots of each cultivar. Specific cultivars included in each experiment were decided by cooperating seed companies.

${ }^{\mathrm{b}}$ Mean severity of bulb rot rated after approximately 4.5 months in storage, on a scale of 0 to 100 where $0=$ no symptoms and 1 to $100=$ percentage of the cut bulb surface area showing symptoms of bacterial rot. Incidence of bulb rot = percentage of the bulbs rated that had symptoms of bacterial bulb rot.

${ }^{\mathrm{c}}$ In the 2007-08 experiment, 10 bulbs were selected randomly from the center of one plot per cultivar for each of two inoculation treatments: (i) injection with E. cloacae, and (ii) noninoculated. Each data point is the mean of 10 bulbs. In the 2008-09 experiment, 10 bulbs were selected randomly from the center of each of three replicate plots per cultivar for each of three inoculation treatments: (i) injection with E. cloacae, (ii) noninoculated, and (iii) injection with sterile water. Each data point is the mean of 10 bulbs for each of three replications.

${ }^{\mathrm{d}}$ Means arranged in descending order of severity ratings for bulb inoculated with E. cloacae in the 2008-09 experiment. For cultivars evaluated only in 2007-08, means are similarly in descending order of severity for bulbs inoculated with E. cloacae. - - indicates the cultivar was not included in that experiment.

${ }^{\text {e }}$ Fisher's protected least significant difference (LSD) for severity of bulb rot for E. cloacae-inoculated and noninoculated bulbs in the 2007-08 experiment, and for E. cloacae-inoculated, noninoculated, and water-inoculated bulbs in the 2008-09 experiment. 
tion on a $2 \%$ agarose gel (27). E. cloacae ATCC 13047, E. aerogenes ATCC 13048, and Cronobacter sakazakii ATCC 29004 (formerly Enterobacter) were included as known strains. DNA banding patterns of the bulb isolates were compared with that of the known species: E. cloacae produced two amplicons (125 and $400 \mathrm{bp})$, E. aerogenes produced three bands (125, 200, and 400 bp), and $C$. sakazaki produced six bands $(125,200,275,350,400$, and $600 \mathrm{bp})$.

A cell lysis PCR assay (30) was used to screen the putative Burkholderia isolates (1). Bacterial cells were transferred to 0.2$\mathrm{ml}$ PCR tubes, and $24 \mu \mathrm{l}$ of PCR reagents was added as described above. Primers CMG-23-1 (5'-ATAGCTGGTTCTCTC CGAA-3') and CM-23-2 (5'-CTCTCCTAC CATGCGYGC-3') were used to identify isolates of B. cepacia, and CMG-16-1 (5'GAGTTTGATCMTGGCTCAG-3') and G16-2 (5'-CGAAGGATATTAGCCCTC-3') were used to identify isolates of $B$. gladioli (1). Parameters of the PCR reaction were $95^{\circ} \mathrm{C}$ for $5 \mathrm{~min}$ to lyse the bacterial cells; followed by $95^{\circ} \mathrm{C}$ for $30 \mathrm{~s}, 57^{\circ} \mathrm{C}$ for $30 \mathrm{~s}$, and $72^{\circ} \mathrm{C}$ for $45 \mathrm{~s}$ for 25 cycles; followed by $72^{\circ} \mathrm{C}$ for $7 \mathrm{~min}$. Agarose gel electrophoresis was completed as described above. B. cepacia strain $\mathrm{Bc} 99-2$ and $B$. gladioli strain Bg 92-1B obtained from Howard Schwartz, Colorado State University, were included as control strains. DNA banding patterns from amplification using primers CMG-23-1 and CM-23-2 were compared to those of B. cepacia which produced one 388-bp amplicon. Likewise, DNA banding patterns generated with primers CMG-16-1 and G-16-2 were compared with that of the $B$. gladioli strain which produced a 468-bp amplicon.

Statistical analyses. Bulb rot severity ratings for the cultivar storage evaluations were subjected to analyses of variance (ANOVAs) using SAS Version 9.2 (SAS Institute, Cary, NC), with cultivar and inoculation treatment as fixed effects and replication as random effects in the model.
A significance level $(P)$ of 0.05 was used for $F$ tests in the ANOVAs. The data were analyzed separately by experiment, as only 33 cultivars were common to both experiments. Mean bulb rot severity ratings were compared using Fisher's protected least significant difference (LSD) at $P<0.05$, based on Friedman's nonparametric rank test because of heterogeneous variances and non-normal distribution of residuals. For the 2007-08 experiment, the 10 bulbs of each cultivar served as replications in the ANOVA, and paired $t$ tests of severity ratings for inoculated versus noninoculated bulbs of each cultivar were calculated. For the 2008-09 experiment, bulbs served as subsamples within each inoculation-bycultivar treatment combination, and the three replicate plots from which the bulbs were harvested served as replications in the ANOVA. In addition, in 2008-09, ANOVA was calculated for bulb severity ratings based on bulb color, with bulb color and inoculation treatment as fixed

Table 1. (continued from previous page)

\begin{tabular}{|c|c|c|c|c|c|c|c|}
\hline \multirow[b]{3}{*}{ Onion cultivar } & \multirow[b]{3}{*}{ Seed company } & \multirow[b]{3}{*}{ Bulb color } & \multicolumn{5}{|c|}{ Mean severity (incidence) of bacterial storage rot $^{\text {b }}$} \\
\hline & & & \multicolumn{2}{|c|}{ 2007-08 Experiment ${ }^{\mathrm{c}}$} & \multicolumn{3}{|c|}{ 2008-09 Experiment ${ }^{\mathrm{c}}$} \\
\hline & & & $\begin{array}{c}\text { Inoculated } \\
\text { with E. cloacae }\end{array}$ & Noninoculated & $\begin{array}{c}\text { Inoculated } \\
\text { with } E \text {. cloacae }\end{array}$ & Noninoculated & $\begin{array}{c}\text { Injected } \\
\text { with water }\end{array}$ \\
\hline OLYS03-209 & Crookham Co. & Yellow & - - & - - & $18.0(100.0)$ & $0.0(0.0)$ & $2.3(13.3)$ \\
\hline Orizaba & Seminis Vegetable Seeds & White & $9.5(100.0)$ & $0.0(0.0)$ & $18.0(96.7)$ & $0.0(0.0)$ & $0.0(0.0)$ \\
\hline Generation X & D. Palmer Seeds & Yellow & $7.0(90.0)$ & $0.0(0.0)$ & $17.7(90.0)$ & $0.0(0.0)$ & $1.3(3.3)$ \\
\hline Talon & Bejo Seeds & Yellow & $11.0(90.0)$ & $0.0(0.0)$ & $17.7(100.0)$ & $0.0(0.0)$ & $8.0(13.3)$ \\
\hline Crockett & Bejo Seeds & Yellow & $8.5(90.0)$ & $0.0(0.0)$ & $17.7(83.3)$ & $0.0(0.0)$ & $1.3(3.3)$ \\
\hline Ranchero & Nunhems USA & Yellow & $6.5(100.0$ & $0.0(0.0)$ & $17.3(96.7)$ & $0.0(0.0)$ & $0.0(0.0)$ \\
\hline Legend & Bejo Seeds & Yellow & -- & -- & $17.3(96.7)$ & $0.3(3.3)$ & $0.7(6.7)$ \\
\hline Sabroso & Nunhems USA & Yellow & $11.0(90.0)$ & $0.0(0.0)$ & $17.3(93.3)$ & $0.7(3.3)$ & $3.3(3.3)$ \\
\hline Salsa & Nunhems USA & Red & $7.5(100.0)$ & $0.0(0.0)$ & $16.7(93.3)$ & $0.0(0.0)$ & $0.0(0.0)$ \\
\hline Rainier & Seminis Vegetable Seeds & White & - - & - - & $16.7(86.7)$ & $0.0(0.0)$ & $0.0(0.0)$ \\
\hline Gunnison & Bejo Seeds & Yellow & $11.5(100.0)$ & $0.0(0.0)$ & $16.3(90.0)$ & $0.0(0.0)$ & $0.7(6.7)$ \\
\hline Frontier & American Takii & Yellow & $9.5(100.0)$ & $0.0(0.0)$ & $16.3(90.0)$ & $0.0(0.0)$ & $0.3(3.3)$ \\
\hline $\mathrm{T}-433$ & American Takii & Yellow & $6.5(100.0)$ & $0.0(0.0)$ & $16.0(93.3)$ & $0.3(3.3)$ & $0.7(3.3)$ \\
\hline White Cloud & Crookham Co. & White & - - & -- & $16.0(86.7)$ & $3.0(6.7)$ & $1.3(13.3)$ \\
\hline Tamara & Bejo Seeds & Yellow & $7.5(90.0)$ & $0.0(0.0)$ & $15.3(86.7)$ & $0.0(0.0)$ & $1.3(6.7)$ \\
\hline Centerstone & American Takii & Yellow & $7.0(90.0)$ & $0.0(0.0)$ & $15.3(90.0)$ & $0.0(0.0)$ & $0.0(0.0)$ \\
\hline RE-E & Nippon Norin & Yellow & -- & -- & $15.3(73.3)$ & $1.0(3.3)$ & $5.7(30.0)$ \\
\hline Redwing & Bejo Seeds & Red & $6.0(90.0)$ & $0.0(0.0)$ & $10.0(80.0)$ & $0.0(0.0)$ & $8.0(13.3)$ \\
\hline Red Bull & Bejo Seeds & Red & $6.1(100.0)$ & $0.0(0.0)$ & $9.0(70.0)$ & $0.0(0.0)$ & $3.3(10.0)$ \\
\hline Snowflake & Bejo Seeds & White & $16.0(100.0)$ & $0.0(0.0)$ & -- & - - & - - \\
\hline DPS1418 & D. Palmer Seeds & Yellow & $12.0(100.0)$ & $0.0(0.0)$ & - - & - - & - - \\
\hline Peso & Bejo Seeds & Yellow & $11.0(90.0)$ & $0.0(0.0)$ & - - & - - & -- \\
\hline Nobility & Crookham Co. & Yellow & $10.5(100.0)$ & $0.0(0.0)$ & - - & - - & - - \\
\hline DPS1413 & D. Palmer Seeds & Yellow & $10.0(100.0)$ & $0.0(0.0)$ & - - & -- & - - \\
\hline DPS1414 & D. Palmer Seeds & Yellow & $10.0(90.0)$ & $0.0(0.0)$ & - - & -- & - - \\
\hline Grand Coulee & Nunhems USA & Yellow & $10.0(100.0)$ & $0.0(0.0)$ & - - & -- & - - \\
\hline XP7011 & Seminis Vegetable Seeds & Yellow & $10.0(100.0)$ & $0.0(0.0)$ & -- & -- & -- \\
\hline DPS1419 & D. Palmer Seeds & Yellow & $9.5(90.0)$ & $0.0(0.0)$ & - - & - - & - - \\
\hline XP18304 & Seminis Vegetable Seeds & Yellow & $9.5(90.0)$ & $0.0(0.0)$ & - - & - - & - - \\
\hline DPS1415 & D. Palmer Seeds & Yellow & $9.0(100.0)$ & $0.0(0.0)$ & - - & - - & - - \\
\hline Spanish Medallion & Sakata Seed America & Yellow & $9.0(90.0)$ & $0.0(0.0)$ & - - & - - & - - \\
\hline XP15875 & Seminis Vegetable Seeds & Yellow & $9.0(100.0)$ & $0.0(0.0)$ & -- & - - & -- \\
\hline Desperado & Bejo Seeds & Yellow & $8.5(90.0)$ & $0.0(0.0)$ & - - & - - & - - \\
\hline Charismatic & Seminis Vegetable Seeds & Yellow & $8.0(90.0)$ & $0.0(0.0)$ & - - & - - & - - \\
\hline DPS1416 & D. Palmer Seeds & Yellow & $8.0(90.0)$ & $0.0(0.0)$ & - - & - - & - - \\
\hline Toluca & Seminis Vegetable Seeds & White & $8.0(100.0)$ & $0.0(0.0)$ & - - & - - & - - \\
\hline White Wing & Bejo Seeds & White & $7.5(90.0)$ & $0.0(0.0)$ & - - & - - & - - \\
\hline Grateful Red & Seminis Vegetable Seeds & Red & $6.7(80.0)$ & $0.0(0.0)$ & - - & -- & - - \\
\hline BGS231 & Bejo Seeds & Yellow & $6.0(70.0)$ & $0.0(0.0)$ & -- & -- & -- \\
\hline DPS1417 & D. Palmer Seeds & Yellow & $6.0(90.0)$ & $0.0(0.0)$ & - - & - - & - - \\
\hline Harmony & Crookham Co. & Yellow & $4.5(50.0)$ & $0.5(20.0)$ & -- & -- & -- \\
\hline $\mathrm{LSD}^{\mathrm{e}}$ & & & & & & 4.82 & \\
\hline
\end{tabular}


effects and replication as a random effect. for mean bulb rot severity ratings and mean incidence of symptomatic bulbs for the 33 cultivars in both experiments to assess consistency in severity ratings for these cultivars under the conditions of the two storage experiments.

\section{RESULTS}

Onion bulb inoculation with $E$. cloacae . In both the 2007-08 and 2008-09 experiments, inoculation of onion bulbs with $E$. cloacae at the shoulder/base of the neck at harvest significantly $(P<0.05)$ increased both the incidence and severity of bacterial storage rot after 4.5 months in storage compared to the noninoculated control bulbs. The primary symptom was a light yellow-brown discoloration of one to three internal fleshy scales, primarily in the upper half of the bulb at the point of injection of E. cloacae (Fig. $1 \mathrm{~A}$ and B). Some inoculated bulbs displayed darker brown discoloration in association with the inoculation site.

2007-08 experiment. The mean severity of bacterial storage rot was $0.1 \%$ for noninoculated bulbs and $9.2 \%$ for inoculated bulbs of all 55 cultivars. Only 5 of $>500$ noninoculated bulbs displayed symptoms of bacterial storage rot, demonstrating a low incidence of natural bulb infection. One inoculated bulb of DPS1413 and one noninoculated bulb of Milestone were totally rotted, which is characteristic of infections caused by $P$. carotovorum and/or Dickeya spp. (34). Complete soft rot of the bulb precluded identification of Enterobacter bulb decay, so these two bulbs were excluded from the ANOVAs. The main effect of inoculation treatment was significant $(P<0.0001)$ for severity of bulb rot. Correlation coefficients were calculated

Inoculation of onion bulbs with E. cloacae significantly increased the incidence of bacterial storage rot to 50 to $100 \%$ per cultivar for inoculated bulbs. Nevertheless, bacterial storage rot symptoms were not very severe overall for inoculated bulbs as the mean severity ratings for individual cultivars ranged from $4.5 \%$ for Harmony to $18.5 \%$ for Tequila (Table 1) even when disease incidence was high. Although the main effect of cultivar was not significant $(P=0.49)$, there was a significant interaction between cultivar and inoculation $(P=$ $0.004)$, i.e., cultivars differed significantly in response to inoculation with E. cloacae.

Paired $t$ tests of severity ratings for inoculated versus noninoculated bulbs of each cultivar were significant $(P<0.05)$ for 54 of the 55 cultivars (data not shown). Harmony was the only cultivar with a nonsignificant paired $t$ test, indicating that inoculation of bulbs of this cultivar with E. cloacae did not increase severity of bacterial storage rot significantly. Inoculated bulbs of Harmony had the lowest mean severity rating $(4.5 \%)$, with only $50 \%$ of the bulbs displaying bacterial storage rot symptoms (Table 1). In contrast, mean severity ratings were highest for Tequila (18.5\%), followed by OLYSO5N5 $(17.0 \%)$, Snowflake (16.0\%), and Montero $(15.5 \%)$. Other than Harmony, the remaining 50 cultivars had mean severity ratings ranging from 6.0 to $12.0 \%$. The mean \pm standard error of severity ratings for inoculated bulbs of red, white, and yellow cultivars were $7.0 \pm 0.05,11.0 \pm 2.3$, and $9.3 \pm$ $0.3 \%$, respectively. This suggested that, on average, the five red cultivars were less susceptible to Enterobacter bulb decay than the four white cultivars and 46 yellow cultivars evaluated during the 2007-08 experiment.

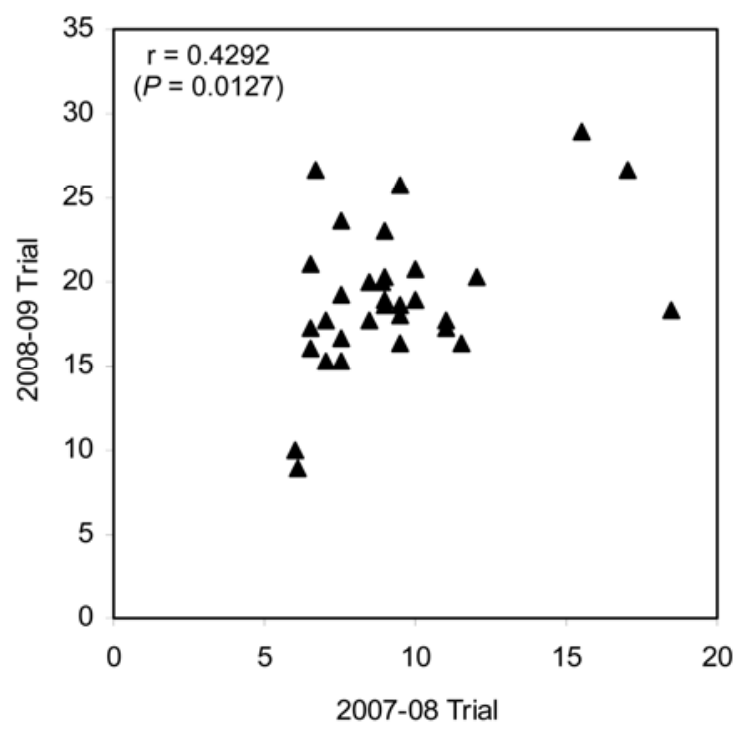

Fig. 2. Mean severity of Enterobacter bulb decay for 33 onion cultivars inoculated with Enterobacter cloacae in the 2007-08 and 2008-09 Onion Cultivar Storage Trials at Washington State University. For the 2007-08 experiment, each mean is the average rating of 10 inoculated bulbs of a cultivar. For the 2008-09 experiment, each mean is the average rating of 10 inoculated bulbs for each of three replicate plots of a cultivar. Bulbs were injected with E. cloacae at harvest and rated for severity of bacterial rot after 4.5 months in storage.
2008-09 experiment. Inoculation of onion bulbs with $E$. cloacae significantly increased severity of Enterobacter bulb decay $(P<0.0001)$. Injecting onion bulbs with water also significantly $(P<0.05)$ increased severity of bacterial rot compared to noninoculated bulbs, but less than for bulbs injected with E. cloacae. The mean severity of bacterial storage rot was $0.4 \%$ for noninoculated bulbs, $1.6 \%$ for bulbs injected with water, and $19.1 \%$ for bulbs injected with $E$. cloacae. The mean incidence of symptomatic bulbs per cultivar ranged from 0 to $6.7 \%$ for noninoculated bulbs, 0 to $30.0 \%$ for bulbs injected with water, and 70 to $100 \%$ for E. cloacae-inoculated bulbs. Only 10 of $>1,300$ noninoculated bulbs displayed symptoms of bacterial rot, demonstrating a low incidence of natural bulb rot. Only 70 of $>1,300$ bulbs injected with water developed symptoms of bacterial rot. The interaction of inoculation with cultivar was significant $(P<0.0001)$, although the main effect of cultivar was not significant $(P=$ 0.40 ), i.e., cultivars differed significantly in response to the three inoculation treatments. Overall, mean severity ratings for inoculated bulbs ranged from 9.0 to $29.0 \%$. Inoculated bulbs of Red Bull and Redwing had the lowest severity ratings (9.0 and $10.0 \%$, respectively) with only 70 to $80 \%$ of the inoculated bulbs symptomatic. The next lowest severity rating was $15.3 \%$ for Centerstone, RE-E, and Tamara (Table 1). In contrast, severity ratings were highest $(>25 \%)$ for Montero, XON 550, OLYSO5-N5, Joaquin, and OLYS03-207. Mean severity ratings for the other cultivars ranged from 16.0 to $23.7 \%$. None of the cultivars showed severity ratings significantly greater than $0 \%$ for the noninoculated bulbs (Table 1). However, for bulbs injected with water, four cultivars (OLYX05-26, RE-E, Redwing, and Talon) had severity ratings significantly greater than $0 \%$ (5.7 to $9.7 \%$ ).

There was a significant interaction between bulb color and inoculation treatment $(P<0.001)$. The means \pm standard error of bulb rot severity for $E$. cloacae-inoculated bulbs were $5.5 \pm 0.6,6.6 \pm 0.7$, and $7.3 \pm$ $0.2 \%$ for the four red, four white, and 39 yellow cultivars, respectively. Based on Fisher's LSD, the red cultivars had significantly less severe bulb rot than the white cultivars, which had less severe rot than the yellow cultivars. There were no significant differences among the three bulb colors for severity ratings of water-inoculated bulbs or noninoculated bulbs.

Correlation coefficients. Of the 69 cultivars evaluated over the duration of this study, 33 were included in both the 2007 08 and 2008-09 experiments. Pearson's correlation coefficient for 2007-08 versus 2008-09 mean bulb rot severity ratings for the 33 cultivars in both experiments was significant ( $r=0.43$ at $P=0.01$ ) (Fig. 2), i.e., cultivars with lower severity ratings in 
2007-08 tended to show low severity ratings in 2008-09, and vice versa. For example, Redwing, Red Bull, T-433, Centerstone, and Salsa were among the 10 cultivars with the lowest severity ratings in both experiments; whereas Montero, OLYS05N5, Caveat, and Granero were among the 10 cultivars with the highest severity ratings in both experiments (Table 1). However, some cultivars displayed very different severity ratings between the two experiments, e.g., Gunnison and Tequila.

Pearson's correlation coefficient for mean severity ratings versus incidence of bulb rot for the 47 cultivars in the 2008-09 experiment was significant $(r=0.58$ at $P<$ $0.0001)$. In contrast, severity and incidence ratings were not significantly correlated for the 55 cultivars evaluated in the 200708 experiment $(r=0.20$ at $P=0.14)$. Interestingly, in the 2008-09 experiment, the incidence of bulbs with bacterial rot was negatively correlated for bulbs injected with water versus bulbs injected with $E$. cloacae $(r=-0.41$ at $P=0.004)$. For example, Redwing, RE-E, and Generation X bulbs injected with water had significant bulb rot ratings, whereas two of these cultivars had low bulb rot ratings when injected with E. cloacae (Table 1).

Bacterial isolations and identification. For isolations carried out from the 200708 storage evaluations, 12 isolates were obtained from a total of five noninoculated, symptomatic bulbs sampled, of which only one bacterial isolate was a putative Enterobacter species based on biochemical assays. The isolate was confirmed by PCR assay to be E. cloacae (data not shown). For the 2008-09 storage evaluations, putative Enterobacter or Burkholderia species were not isolated from any of four noninoculated, symptomatic onion bulbs or five water-injected, symptomatic bulbs assayed. Fifty-five symptomatic onion bulbs (one per cultivar) inoculated with E. cloacae produced isolates that were verified as Enterobacter species by biochemical assays and then confirmed by PCR assay as E. cloacae for 39 of the 55 cultivars (data not shown). One isolate from a symptomatic, inoculated bulb was preliminarily identified by biochemical assays as a Burkholderia species, but was not confirmed as $B$. cepacia or B. gladioli by PCR assay. Pectobacterium, Dickeya, and Pantoea species were not isolated from any of the symptomatic onion bulbs sampled.

\section{DISCUSSION}

The current limited biological understanding of onion bulb rots caused by bacterial plant pathogens such as B. cepacia, $B$. gladioli pv. alliicola, and E. cloacae translates into a reduced ability to develop effective management strategies for onion growers and packers (5). In general, the few effective management options available for bacterial plant pathogens include cultural practices (e.g., drip versus overhead irrigation), sanitation, and planting resistant cultivars, when available $(11,34)$. Chemical control measures for bacterial diseases tend to be of limited and primarily protective efficacy, and the use of antibiotics to control bacterial plant diseases is restricted by costs and the risk of developing antibiotic resistance in bacterial populations $(15,21)$. Consequently, the use of resistant cultivars can be very important for managing bacterial plant diseases.

The ability to breed onions for resistance to bacterial diseases is dependent on identifying potential sources of resistance to specific pathogens. E. cloacae appears to be associated with onion storage rots in the semiarid western United States with increasing prevalence (B. K. Schroeder and L. J. du Toit, personal observation), but little is known about how this pathogen interacts with onion plants and bulbs. In this study, 69 storage onion cultivars were evaluated for susceptibility to artificial inoculation with E. cloacae, of which 33 cultivars were tested in both years of the study. Seed companies that participate in the annual WSU Onion Cultivar Trial select their specific cultivars to be evaluated each year. Therefore, we did not have any control over which onion cultivars were included in each trial. However, participating companies typically submit cultivars that are widely planted in the Pacific Northwest as well as any new lines that are close to being made available commercially. Therefore, the results for those cultivars tested in only 1 year are also reported in this study for informational purposes but should be viewed as preliminary until they can be repeated. This study represents an important step toward identifying potential sources of resistance. The 69 cultivars represent the diversity of storage onion cultivars grown commercially in the semiarid Columbia Basin in Washington, as well as experimental cultivars being developed for this region. Differences observed among cultivars following inoculation of bulbs with E. cloacae at harvest and storage of the bulbs in commercial storage facilities suggest it should be possible to select for reduced susceptibility to Enterobacter bulb decay in storage cultivars. Other bacterial pathogens of onion can cause bulb rots individually and in mixed infections (34). The protocol used in this study to screen onion cultivars for resistance to $E$. cloacae may be used to screen for resistance to other bacterial pathogens. Wright and Grant (39) used a leaf inoculation assay to evaluate Allium germplasm for resistance to Pseudomonas marginalis and Pseudomonas viridiflava in a greenhouse study (37). They demonstrated that A. cepa entries in that collection were very susceptible to these two pathogens, but other Allium species evaluated were resistant and represented potential sources of resistance for onion breeders (39).
The method of inoculation of a pathogen can significantly influence results of germplasm resistance assays. Ideally, the inoculation method should (i) produce symptoms that reflect symptoms observed under natural infection conditions, (ii) give reproducible results, and (iii) not circumvent innate biological mechanisms of resistance. Injection was used to inoculate onion bulbs with E. cloacae in this study because of the efficiency of this method for evaluating large numbers of bulbs. Injecting $5 \times 10^{7} \mathrm{CFU}$ of E. cloacae per bulb resulted in reproducible bulb rot symptoms comparable to those observed in naturally infected bulbs $(11,29,34,35)$. This high inoculum concentration used was determined to provide reproducible bulb rot evaluations that permitted differentiation of a range of responses among onion cultivars (B. K. Schroeder and M. L. Canady, data not published). However, a lessinvasive inoculation method might enable other aspects of the infection process to be evaluated, and might avoid circumventing potential resistance mechanisms associated with movement of the pathogen from the foliage down the neck and into the bulb. This could potentially be accomplished by spraying inoculum of the pathogen onto the foliage and necks of onion plants in the field prior to harvest. Spray inoculation was not used in this study because the cultivar trials were located within growercooperator onion crops destined for commercial markets. Hence, the bulbs were inoculated after topping and harvest to avoid contaminating the growers' crops. Further research is needed to improve our understanding of the infection process of E. cloacae in onion plants, the route of entry of the pathogen into bulbs, and the influence of environmental conditions and cultural practices on movement of the pathogen into onion bulbs to develop an inoculation protocol that mimics the natural route of infection.

Anecdotal evidence in Washington State suggests that onion growers and packers consider bulbs of red cultivars to be more susceptible than white or yellow cultivars to bacterial rots in storage (W. Huppert, personal communication). However, the red cultivars evaluated in this study were more resistant to inoculation with E. cloacae than the white and yellow cultivars. In contrast, for bulbs injected with water in the second year of this study, several red cultivars developed significant levels of storage rot from which bacteria other than E. cloacae were isolated. This suggests that natural latent infection of bulbs of these red cultivars may have been triggered to become active infections as a result of injecting water into the bulbs. Although injecting the bulbs may have provided a wound for microorganisms on the surface of the bulb, the injection site on each bulb was surface-sterilized with alcohol immediately prior to injecting E. cloacae or 
water, which should have minimized this route of entry of other microorganisms on the bulb surface. Consequently, symptoms observed on onion bulbs injected with water may have arisen from endophytic bacteria present in these bulbs prior to injection. The discrepancy in reaction of the red cultivars to E. cloacae versus empirical grower observations in the region probably also reflects, in part, the difficulty stakeholders and researchers have in accurately identifying specific causal agents of bacterial storage rots of onion bulbs, particularly as multiple genera and/or species can readily be isolated from individual symptomatic bulbs $(9-11,34)$.

Many factors can influence development of bacterial storage rots, including crop maturity at harvest and wounding of bulbs during harvest and sorting prior to storage. The significance of these factors in outbreaks of Enterobacter bulb decay remains to be determined. Although rainfall close to harvest of an onion crop does not appear to be necessary for Enterobacter bulb decay to develop in storage (11), the impact of using overhead irrigation, particularly with surface or recycled water, needs clarification (11,23,34). Similarly, Enterobacter bulb decay may be affected by curing practices for storage onions. Curing is the process of drying onion bulbs using forced air to produce tight wrapper scales and a dry neck. This prevents excessive moisture loss during storage (shrinkage) and movement of fungal pathogens such as Botrytis species (cause of neck rot) (6) from the neck into the fleshy bulb scales (3). Bulbs are cured using forced ambient air (24 to $27^{\circ} \mathrm{C}$ ) for 2 to 3 weeks, or forced heated air $\left(29\right.$ to $\left.35^{\circ} \mathrm{C}\right)$ for 4 days or longer. The storage temperature is then decreased 1 to $5^{\circ} \mathrm{C}$ per day once relative humidity of air exiting the storage facility is $<70 \%$ $(3,11,22)$. The higher the temperature and the longer the duration of this curing process, the more optimal conditions may become for E. cloacae based on conditions that favor this bacterium (24). However, the impact of curing temperatures and durations on Enterobacter bulb decay remains to be determined. Preliminary evaluations suggest higher curing temperatures over longer durations exacerbate the disease (31). The onion bulbs used in this study were cured under commercial conditions at different storage facilities with different curing parameters each season. The duration of forced air used for curing in the 2007-08 experiment was $24 \mathrm{~h}$ versus 10 days in the 2008-09 experiment. The duration it then took to get onion bulbs cooled for long-term storage was 7 days in the 2007-08 experiment versus 30 days in the 2008-09 experiment. The range of mean severity ratings of bacterial storage rot observed in the 2008-09 experiment was greater than in the 2007-08 experiment, suggesting that curing parameters may have influenced Enterobacter bulb decay. However, cultivars may also differ in physiological response to curing parameters, which may have contributed to differential responses of some cultivars (e.g., Gunnison and Tequila) to inoculation with E. cloacae in the 2007-08 experiment versus the 2008-09 experiment. Furthermore, the nature of this study did not permit each cultivar to be harvested at optimum physiological maturity. The trials were in grower's fields, so timing of harvest was determined by maturity of the surrounding cultivar (Tamara in 2007 and Crockett in 2008). Bulbs of some cultivars were less or more mature than optimal at the time of harvest, which may have impacted consistency of cultivar responses to E. cloacae between the 2007-08 and 2008-09 experiments.

The frequency with which $E$. cloacae was reisolated in 2008-09 from a sampling of 55 E. cloacae inoculated and symptomatic onion bulbs (one per cultivar) was only $71 \%$. Similar observations were made by Nishijima et al. (20), who reported 75 to $80 \%$ recovery for $E$. cloacae from inoculated macadamia nuts. They speculated this may have been the result of E. cloacae being present in a "viable but not culturable state", as reported for E. cloacae on leaves of spring barley (Hordeum vulgare) and dwarf bean (Phaseolus vulgaris), as well as from soil (22). In the 2008-09 experiment in this study, the frequency with which bacteria other than E. cloacae were isolated from nine symptomatic, noninoculated onion bulbs was $9 \%$. Cother and Dowling (9) isolated bacteria from symptomatic, naturally infected onion bulbs in Australia. When the isolated bacterial strains were reinoculated into asymptomatic onion bulbs, and they attempted to reisolate the pathogens to complete Koch's postulates, other bacteria were recovered in addition to the original isolates. In particular, Pseudomonas aeruginosa along with species of Klebsiella, Erwinia, Bacillus, Serratia, and Enterobacter were recovered. Cother and Dowling (9) also observed that the frequency with which they isolated a second bacterium along with the original isolate increased in bulbs stored for a longer duration compared to bulbs stored for a shorter period. A second bacterium was isolated along with the original bacterium from approximately $25 \%$ of the older bulbs versus none of the younger bulbs. They speculated that these "secondary" bacteria were part of the natural microflora in onion bulbs, which increased in number in physiologically older bulbs to cause bulb rot symptoms. In this study, a significant negative correlation in bulb rot severity was detected for bulbs injected with water versus bulbs injected with $E$. cloacae in 2008-09. This is illustrated in particular by the cultivars Redwing and RE-E, for which bulbs injected with water exhibited significant bacterial rot even though these cultivars showed relatively resistant reactions (low severity ratings) when injected with E. cloacae. For the bulbs injected with water, the presence of additional water in the fleshy scales may have stimulated the growth of latent bacterial bulb rot pathogens. Such induction of resident bacterial microflora from latent to active form by the addition of water into the fleshy scales of onion bulbs complicates attempts to isolate the primary causal agent of bulb rots.

Increasing our understanding of the ecology of E. cloacae and epidemiology of Enterobacter bulb decay will provide tools to develop more effective control measures for this pathogen. Further screening of more diverse onion germplasm, particularly parent (inbred) lines used in hybrid production and/or the USDA germplasm collection, could identify sources of resistance to E. cloacae for onion breeding programs. Studies evaluating the influence of curing parameters on this disease could also help define parameters that minimize the impact of Enterobacter bulb decay in storage. Greater understanding of the infection process of E. cloacae in onion could help with development of a disease assay that is less invasive than the inoculation method used in this study, and enable evaluation of the impact of onion grower practices (e.g., irrigation, copper sprays, undercutting, topping of bulbs) on development of Enterobacter bulb decay in storage.

\section{ACKNOWLEDGMENTS}

The authors gratefully acknowledge financial support for this project from the Pacific Northwest Vegetable Association, the Washington State Commission for Pesticide Registration, and a 2006-07 Washington State University New Faculty Seed Grant. Invaluable in-kind support was provided by Hartley Farms and Carr Farms for serving as host farms for field and storage evaluations in the WSU Onion Cultivar Trial in 2007-08 and 2008-09, respectively. In addition, excellent technical support was provided by Mike Derie, Barbara Holmes, Jenette Anderson, and regional onion stakeholders for harvest, inoculation, and/or storage evaluations. This project was supported by the Department of Plant Pathology (PPNS No. 0525) in the Washington State University College of Agricultural, Human and Natural Resource Sciences, and the Washington State University Agricultural Research Center for CRIS Project No. WNPO0652.

\section{LITERATURE CITED}

1. Bauernfeind, A., Schneider, I., Jungwirth, R., and Roller, C. 1998. Discrimination of Burkholderia gladioli from other Burkholderia species detectable in cystic fibrosis patients by PCR. J. Clin. Microbiol. 36:2748-2751.

2. Bishop, A. L., and Davis, R. M. 1990. Internal decay of onions caused by Enterobacter cloacae. Plant Dis. 74:692-694.

3. Brewster, J. L. 2006. Onions and Other Vegetable Alliums. Crop Production Science in Horticulture Series No. 3. CAB International, Wallingford, UK.

4. Carter, J. C. 1945. Wetwood of elms. III. Nat. Hist. Surv. Bull. 23:407-448.

5. Ceponis, M. J., Cappellini, R. A., and Lightner, G. W. 1986. Disorders in onion shipments to the New York Market, 1972-1984. Plant Dis. 70:988-991.

6. Chilvers, M. I., and du Toit, L. J. 2006. Detec- 
tion and identification of Botrytis species associated with neck rot, scape blight, and umbel blight of onion. Online. Plant Health Progress doi:10.1094/PHP-2006-1127-01-DG.

7. Chun, W., and Jones, J. B. 2001. Burkholderia. Pages 139-150 in: Laboratory Guide for Identification of Plant Pathogenic Bacteria. N. W. Schaad, J. B. Jones, and W. Chun, eds. American Phytopathological Society, St. Paul, MN.

8. Clementino, M. M., de Filippis, I., Nascimento, C. R., Branquinho, R., Rocha, C. L., and Martins, O. B. 2001. PCR analyses of tRNA intergenic spacer, 16S-23S internal transcribed spacer, and randomly amplified polymorphic DNA reveal inter- and intraspecific relationships of Enterobacter cloacae strains. J. Clin. Microbiol. 39:3865-3870.

9. Cother, E. J., and Dowling, V. 1986. Bacteria associated with internal breakdown of onion bulbs and their possible role in disease expression. Plant Pathol. 35:329-336.

10. Fallquist, H. M., Canady, M., du Toit, L. J., and Schroeder, B. K. 2007. Association of Enterobacter spp. with onion plants exhibiting premature leaf dieback in the Columbia Basin of Washington State. (Abstr.) Phytopathology 97:S34.

11. Gent, D. H. 2008. Enterobacter bulb decay. Pages 67-68 in: Compendium of Onion and Garlic Diseases and Pests. 2nd ed. H. F. Schwartz and S. K. Mohan, eds. American Phytopathological Society, St. Paul, MN.

12. George, M., Potty, V. P., and Jayasankar, N. P. 1976. Association of Enterobacter with coconut root (wilt) disease. Curr. Sci. 45:677-678.

13. Hoffmann, H., Stindl, S., Ludwig, W., Stumpf, A., Mehlen, A., Heesemann, J., Monget, D., Schleifer, K. H., and Roggenkamp, A. 2005. Reassignment of Enterobacter dissolvens to Enterobacter cloacae as E. cloacae subspecies dissolvens comb. nov. and emended description of Enterobacter asburiae and Enterobacter kobei. Syst. Appl. Microbiol. 28:196-205.

14. Jang, E. B., and Nishijima, K. A. 1990. Identification and attractancy of bacteria associated with Dacus dorsalis (Diptera, Tephritidae). Environ. Entomol. 19:1726-1731.

15. Levy, S. B. 1998. The challenge of antibiotic resistance. Sci. Am. 278:46.

16. Marchini, D., Rosetto, M., Dallai, R., and Marri, L. 2002. Bacteria associated with the oesophageal bulb of the medfly Ceratitis capitata (Diptera:Tephritidae). Curr. Microbiol.
44:120-124.

17. Murdoch, C. W., and Campana, R. J. 1983. Bacterial species associated with wetwood of elm. Phytopathology 73:1270-1273.

18. Nishijima, K. A., Alvarez, A. M., Hepperly, P. R., Shintaku, M. H., Keith, L. M., Sato, D. M., Bushe, B. C., Armstrong, J. W., and Zee, F. T. 2004. Association of Enterobacter cloacae with rhizome rot of edible ginger in Hawaii. Plant Dis. 88:1318-1327.

19. Nishijima, K. A., Couey, H. M., and Alvarez, A. M. 1987. Internal yellowing, a bacterial disease of papaya fruits caused by Enterobacter cloacae. Plant Dis. 71:1029-1034.

20. Nishijima, K. A., Wall, M. M., and Siderhurst, M. S. 2007. Demonstrating pathogenicity of Enterobacter cloacae on macadamia and identifying associated volatiles of gray kernel of macadamia in Hawaii. Plant Dis. 91:12211228.

21. Nwosu, V. C. 2001. Antibiotic resistance with particular reference to soil microorganisms. Res. Microbiol. 152:421-430.

22. Pederson, J. C., and Leser, T. D. 1992. Survival of Enterobacter cloacae on leaves and in soil detected by immunofluorescence microscopy in comparison with selective plating. Microb. Rel. 1:95-102.

23. Pelter, G. Q., and Sorensen, E. J. 2004. Crop profile for onions in Washington. U.S. Dep. Agric. National Information System Pest Management Center. http://www.ipmcenters.org/ cropprofiles/

24. Richard, C. 1984. Genus VI. Enterobacter Hormaeche and Edwards 1960, 72; Nom. Cons. Opin. 28, Jud. Comm. 1963, 38. Pages 465-469 in: Bergey's Manual of Systemic Bacteriology. Vol. I. N. R. Kreig and J. G. Holt, eds. Williams \& Wilkins, Baltimore, MD.

25. Rosen, H. R. 1922. The bacterial pathogen of corn stalk rot. Phytopathology 12:497-499.

26. Rossiter, M. C., Howard, D. J., and Bush, G. L. 1983. Symbiotic bacteria of Rhagoletis pomonella. Pages 77-84 in: Fruit Flies of Economic Importance. R. Cavalloro, ed. A. A. Balkema, Rotterdam.

27. Sambrook, J., Frisch, E. F., and Maniatis, T. 1989. Molecular Cloning: A Laboratory Manual. Cold Spring Harbor Laboratory, Cold Spring Harbor, NY.

28. Sanders, W. E., and Sanders, C. C. 1997. Enterobacter spp.: Pathogens poised to flourish at the turn of the century. Clin. Microbiol.
Rev. 10:220-241.

29. Schroeder, B. K., du Toit, L. J., and Schwartz, H. F. 2009. First report of Enterobacter cloacae causing onion bulb rot in the Columbia Basin of Washington State. Plant Dis. 93:323.

30. Schroeder, B. K., House, B. L., Mortimer, M. W., Yurgel, S. N., Maloney, S. C., Ward, K. L., and Kahn, M. L. 2005. Development of a functional genomics platform for Sinorhizobium meliloti: Construction of an ORFeome. Appl. Environ. Microbiol. 71:5858-5864.

31. Schroeder, B. K., Thyren, E., Sires, J. L., and du Toit, L. J. 2008. Development of Enterobacter cloacae on onion plants, and effect of post-harvest curing temperature on development of Enterobacter bulb decay. (Abstr.) Phytopathology 98:S142.

32. Schroeder, B. K., Waters, T., and du Toit, L. J. 2008. Evaluation of onion cultivars for resistance to Enterobacter cloacae in storage, 2007-2008. Plant Dis. Manag. Rep. 2:V159, DOI: 10.1094/PDMR02.

33. Schroeder, B. K., Waters, T., Wohleb, C., and du Toit, L. J. 2009. Evaluation of onion cultivars for resistance to Enterobacter cloacae in storage, 2008-2009. Plant Dis. Manag. Rep. 3:V142, DOI:10.1094/PDMR03.

34. Schwartz, H. F., and Mohan, S. K. 2008. Compendium of Onion and Garlic Diseases and Pests. 2nd ed. American Phytopathological Society, St. Paul, MN.

35. Schwartz, H. F., and Otto, K. 2000. First report of a bulb decay of onion by Enterobacter cloacae in Colorado. Plant Dis. 84:808.

36. Takahashi, Y., Takahashi, K., Sato, M., Watanabe, K., and Kawano, T. 1997. Bacterial leaf rot of Odontioda orchids caused by Enterobacter cloacae. Ann. Phytopathol. Soc. Jpn 63:164-169.

37. Vidaver, A. K. 1967. Synthetic and complex media for the rapid detection of fluorescence of phytopathogenic pseudomonads: Effect of the carbon source. Appl. Microbiol. 15:1523 1524

38. Wick, R. L., Rane, K. K., and Sutton, D. K. 1987. Mung bean sprout disease caused by $E n$ terobacter cloacae. (Abstr.) Phytopathology $77: 123$

39. Wright, P. J., and Grant, D. G. 1998. Evaluation of Allium germplasm for susceptibility to foliage bacterial soft rot caused by Pseudomo nas marginalis and Pseudomonas viridiflava. N.Z. J. Crop Hortic. Sci. 26:17-21 